\title{
Progestins influence performance on cognitive tasks independent of changes in affective behavior
}

\author{
CHERYL A. FRYE \\ State University of New York, Albany, New York \\ and Connecticut College, New London, Connecticut \\ and \\ ELIZABETH H. LACEY \\ Connecticut College, New London, Connecticut
}

\begin{abstract}
In this study, the effects of progestins on various cognitive and affective tasks were investigated. Ovariectomized rats $(N=72$ ) received subcutaneously $0.0,4.0$, or $8.0 \mathrm{mg} / \mathrm{kg}$ of progesterone (P), dihy-

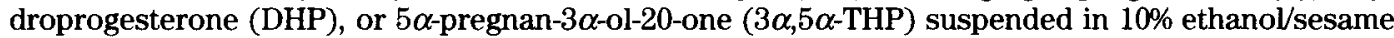
oil v/v. For the cognitive tasks (Y-maze, inhibitory avoidance, and object recognition), the subjects were injected after habituation and training trials and were tested $24 \mathrm{~h}$ later. For the nociception and affective tasks (open field, elevated plus-maze, and tailflick), the subjects were injected 1 or $24 \mathrm{~h}$ before testing. P reduced latencies to the goal arm in the Y-maze, enhanced latencies to the shock-associated side of the inhibitory avoidance chamber, and increased the percentage of time with a novel object. DHP reduced latencies to the goal arm, increased the percentage of correct choices in the Y-maze, and increased crossover latencies in the inhibitory avoidance task. $3 \alpha, 5 \alpha$-THP administration enhanced performance in the inhibitory avoidance task. P, DHP, and $3 \alpha, 5 \alpha$-THP increased the number of entries into the central squares of a brightly lit open field, open arm time in the elevated plus-maze, and tailflick latencies, when administered $1 \mathrm{~h}$, but not $24 \mathrm{~h}$, prior to testing. These data suggest that some progestins, when administered following habituation and training and $24 \mathrm{~h}$ prior to testing, produce changes in cognitive performance that do not coincide with overt changes in the affective behaviors examined.
\end{abstract}

Cognitive changes over endogenous hormone cycles following removal of the ovaries and after hormone replacement suggest that there are activational effects of steroids on cognitive performance. The majority of these studies have focused on estrogen's (E) effects. Systemic $\mathrm{E}$ administration to ovariectomized rats (McCord, Hamlin, Pool, \& Milner, 1979) and mice (Miele, Rosellini, \& Svare, 1988) enhances conditioned aversions and reverses the learning deficits in T-maze performance induced by scopolamine (Dohanich, Fader, \& Javorsky, 1994). Intrahippocampal $E$ to ovariectomized rats significantly improves long-term memory retention in a spatial water maze task, as compared with vehicle-administered controls (Packard \& Teather, 1997). These studies, and others, provide evidence that $E$ has activational effects on cognitive performance in rodents.

Progesterone (P) normally varies with $E$ over endogenous hormonal cycles and may itself have important effects on cognitive performance; however, the effects of

This research was supported by grants from the Whitehall Foundation and the Patrick and Catherine Weldon Donaghue Foundation for Medical Research. Additional support was provided by NSF. Correspondence concerning this article should be addressed to $\mathrm{C}$. A. Frye, Department of Psychology, State University of New York, 1400 Washington St., Albany, NY 12222 (e-mail: cafrye@cnsunix.albany.edu). progestins are generally inconsistent. $P$ over the menstrual cycle is positively correlated with performance on perceptual (Broverman et al., 1981) and visual (Phillips \& Sherwin, 1992a, 1992b) memory tasks. During pregnancy, when $\mathrm{P}$ concentrations are increased above menstrual cycle levels and are high for a longer time, deficits in women's memory have been consistently observed (Brindle, Brown, Brown, Griffith, \& Turner, 1991; Eidelman, Hoffman, \& Kaitz, 1993; Parsons \& Redman, 1991; Sharp, Brindle, Brown, \& Turner, 1993; Silber, Almkvist, Larsson, \& Uvnas-Moberg, 1990; Woodfield, 1984). These findings suggest that either circulating levels of progestins or duration of exposure to progestins can modify effects on cognitive behaviors. Although progestins rarely act without $E$ in a physiological situation, it is necessary to examine them independent of $E$ in order to parse out the relative contributions of each steroid. One of the few studies that enabled the effects of $E$ and $P$ to be differentiated clearly revealed that cognitive performance was enhanced significantly in women who had been administered $\mathrm{P}$, as compared with that of women who had been administered E or gonadotropin-releasing hormone (GNRH) agonist only (Berman et al., 1997).

In rodents, $P$ 's effects on the performance of cognitive tasks when alone or with $E$ are also variable. $P$ when administered with $\mathrm{E}$, completely reversed the learning def- 
icits produced by scopolamine (Dohanich et al., 1994) and enhanced state-dependent learning (Stewart, Krebs, $\&$ Kaczender, 1967). However, $P$ alone has been reported to improve or have no effect on conditioned avoidance (Diaz-Veliz, Urresta, Dussaubat, \& Mora, 1994; Ebner, Richardson, \& Riccio, 1981) and short- and long-term spatial tasks (Frye \& Sturgis, 1995).

Some of the discrepancies in P's effects on cognitive performance may be due to circulating levels and durations of exposure that influence P's bioavailability and that of its metabolites, which have different actions. $P$ and its $5 \alpha$-reduced metabolite dihydroprogesterone (DHP) have a high affinity for intracellular progestin receptors (PRs; Iswari, Colas, \& Karavolas, 1986) but weak activity at $\gamma$-aminobutyric acid (GABA) $)_{\mathrm{A}}$ / benzodiazepine receptor complexes (GBRs; Majewska, Harrison, Schwartz, Barker, \& Paul, 1986). P and DHP can be reduced readily to $5 \alpha$-pregnan-3 $\alpha$-ol-20-one ( $3 \alpha, 5 \alpha$-THP; Karavolas $\&$ Nuti, 1976), which is the most effective endogenous compound at enhancing GABA-stimulated chloride flux in GBRs (Harrison, Majewska, Harrington, \& Barker, 1987; Majewska et al., 1986) but is devoid of activity at PRs. Progestins produce different outcomes on passive avoidance (van Wimersma Greidanus, 1977) and shortand long-term memory performance (Frye \& Sturgis, $1995)$. The fact that $E$ enhances the activity of enzymes that mediate $P$ metabolism (Cheng \& Karavolas, 1973) may underlie differences between studies that have examined the effects of $P$ following $E$ priming and those that have examined $\mathrm{P}$ alone. Hence, the cognitive effect of progestins may be related to the dosage, bioavailability, and/or differential actions of progestins at PRs or GBRs (Frye \& Sturgis, 1995) at the time of testing.

Indeed, the variability in the literature regarding P's cognitive effects also may be related to anxiolytic effects (Bitran, Hilvers, \& Kellogg, 1991 a, 1991b; Mora, Dussaubat, \& Diaz-Veliz, 1996; Wieland, Lan, Mirasedeghi, \& Gee, 1991) secondary to its metabolism to the neurosteroid $3 \alpha, 5 \alpha$-THP. P and DHP have benzodiazepine-like effects at GABA (Majewska et al., 1986; McAuley, Reynolds, Kroboth, Smith, \& Kroboth, 1995; Wu, Gibbs, \& Farb, 1990) and produce analgesia (Frye \& Duncan, 1995) and anxiolysis (Bitran et al., 1991a, 1991b). In drug discrimination tasks, ovariectomized rats generalize P to pentobarbital (Heinsbroek, van Haaren, Zantvoord, \& van de Poll, 1987) and benzodiazepines (Ator, Grant, Purdy, Paul, \& Griffiths, 1993). Notably, blocking P's metabolism by coadministration of a $5 \alpha$-reductase inhibitor, which blocks P's conversion to $3 \alpha, 5 \alpha$-THP (Bitran, Shiekh, \& McLeod, 1995), attenuates its anxiolytic effects. Together, these findings suggest that the ability of $\mathrm{P}$ to be metabolized to DHP or $3 \alpha, 5 \alpha$-THP may mitigate variations in the way progestins alter affective behaviors.

It is unclear whether the effects of progestins on cognitive performance may be due to the nature of the task, altered perception of a task as a result of anxiolysis, altered motor behavior, or true mneumonic changes in cognitive functioning. To examine the effects of progestins on the performance of cognitive tasks (Y-maze, inhibitory avoidance, and object recognition), progestins $(0.0,4.0$, or $8.0 \mathrm{mg} / \mathrm{kg}$ of P, DHP, or $3 \alpha, 5 \alpha$-THP) were administered after habituation and training, and testing occurred $24 \mathrm{~h}$ later. To determine whether the progestin regimens employed altered anxiety-like behaviors, rats were tested in affective tests (open field, elevated plus-maze, and tailflick) $24 \mathrm{~h}$ following administration. Performance in affective tasks was also examined $1 \mathrm{~h}$ following progestin administration (as a positive control). We hypothesize that if progestins have true mneumonic effects, progestin administration will produce differences in cognitive performance $24 \mathrm{~h}$ following administration that are independent of changes in affective behavior.

\section{METHOD}

\section{Animals and Housing}

Female, Long-Evans rats $(N=72)$, approximately 55 days of age, were obtained from Harlan Sprague-Dawley and were housed in hanging stainless steel cages $(24 \times 18 \times 19 \mathrm{~cm})$ in a temperaturecontrolled room $\left(21^{\circ} \pm 1^{\circ} \mathrm{C}\right)$ in the laboratory animal care facility The rats were maintained on a 12:12-h light:dark cycle (lights off, 8:00 a.m.) with access to Purina Rat Chow and tap water in their home cages, unless otherwise specified. Behavioral testing began $1 \mathrm{~h}$ after lights out, when animals normally are most active. Females were ovariectomized 2 weeks prior to behavioral testing. The animals were assigned to receive subcutaneously (s.c.) $0.0,4.0$, or $8.0 \mathrm{mg} / \mathrm{kg}$ of P, DHP, or $3 \alpha, 5 \alpha$-THP suspended in $10 \%$ ethanol $/$ sesame oil $\mathrm{v} / \mathrm{v}$. The hormone regimens utilized were based on our previous research that demonstrated that these dosages produce physiological circulating and central concentrations of $P$ and its metabolites (Frye, Bayon, Pursnani, \& Purdy, 1998). Although the brain normally is not exposed to progestins in the absence of estradiol, progestins were utilized alone, because estradiol and progestins may have synergistic or antagonistic consequences for function, which should to be examined in future studies. For the Y-maze, inhibitory avoidance, and object recognition tests, the subjects were injected after training trials. Open-field, elevated plus-maze, and tailflick testing occurred $\mathrm{I} h$ after injection and again $24 \mathrm{~h}$ later. All the tests were conducted in the same testing room and were counterbalanced to prevent order effects. There was a minimum l-week hormone wash-out period between each behavioral test.

\section{Behavioral Testing}

The cognitive tasks (spatial vs. nonspatial; aversive vs. nonaversive; working vs. long-term memory) were chosen because of the different types of memory they assess; also, these approaches could be utilized with minimal training in order to maximize the possibility that differences between steroids in cognitive performance would be discernable. All the data were collected by trained observers, who were "blind" with respect to treatment conditions A comprehensive description of these methods has been previously published (Frye \& Lacey, 1999; Frye, Petralia, \& Rhodes, 2000).

\section{Y-Maze}

The delayed nonmatching-to-sample Y-maze procedure employed tested working and long-term memory (Aggleton, Blindt, \& Candy, 1989; Frye \& Sturgis, 1995; Kelsey, Sanderson, \& Frye, 2000). The Y-maze consisted of a start arm $(61 \mathrm{~cm}$ long, $13 \mathrm{~cm}$ 
wide, and $30 \mathrm{~cm}$ high) and two goal boxes $(46 \times 15 \times 30 \mathrm{~cm})$ with metal cups ( $1-\mathrm{cm}$ diameter) positioned $0.5 \mathrm{~cm}$ from the end of each arm. A guillotine door enclosed the start box and each goal arm.

Habituation (Day 1): The rats were ad-lib food restricted for $60 \mathrm{~h}$ prior to habituation and throughout testing. During this time, the rats were given three pellets of rodent chow and three Froot Loops daily. On Day 1, the rats explored the maze without the doors for 2 min and ate one half of a Froot Loop at the end of each goal arm. The rats were then placed in the start box with the door down. After $5 \mathrm{sec}$, the door was lifted and closed after they passed it, and they were again allowed to eat the Froot Loops.

Training (Day 2): The rats were trained to alternate between the two goal arms of the maze. The rats were placed in the start box with the door down. One goal arm was closed, whereas the other was open and baited. After $5 \mathrm{sec}$, the start door was lifted and closed when the rats traversed past it. Upon entering the open goal arm, the door was closed, and the rats remained in the arm to eat the bait $(25 \mathrm{sec})$. This forced run was repeated once for the opposite arm, then once again for the original arm, until rats alternated three times in succession in under $2 \mathrm{~min}$ for each trial. There were no differences between groups in the latencies for these trials; average latencies were $98.6 \pm 10.9 \mathrm{sec}$. Immediately following the third training trial, the rats were injected with $\mathrm{P}, \mathrm{DHP}$, or $3 \alpha, 5 \alpha$-THP $(0.0,4.0$, or $8.0 \mathrm{mg} / \mathrm{kg}, \mathrm{s.c}$.).

Testing (Days 3 and 5): The subjects were tested $24 \mathrm{~h}$ following training (Day 3 ) and again $48 \mathrm{~h}$ later to test long-term memory (Day 5) on their ability to alternate between arms of the maze within 10 trials. On both days, the latency to the goal box and the percentage of correct arm entries in 10 trials were measured. A testing trial consisted of a forced run immediately followed by a choice run. During a forced run, one goal arm was closed, whereas the other was open and baited. In the second part of the trial, during the choice run, both goal arm doors were open, and the rats could choose either arm. If the rats chose the correct arm, the arm not previously entered, the rats were closed in the goal box and removed after eating. In the case of an incorrect choice, defined as a return to the arm just visited, the door was shut behind the rats, and the rats remained for $25 \mathrm{sec}$ without a Froot Loop. There was an intertrial interval of $3 \mathrm{~min}$, and the forced arm direction was alternated so that the rats were forced down each arm five times. Average baseline latencies on the forced training trials were $92.9 \pm 13.7 \mathrm{sec}$ and did not differ between groups. On both days, the latency to the goal box and the percentage of correct arm entries in 10 trials were measured. Four-way analysis of variance (ANOVAs), with three withinsubjects factors (Day 3 or 5, Trials 1-10, forced or choice run type) and one between-subjects factor (dosage) analyzed the effects of $P$, DHP, or $3 \alpha, 5 \alpha$-THP on the latency to reach the food cup and the percentage of correct choices. There were differences between trials and run type (data not shown). Latency data presented are for forced and choice trials, which were different on Day 3 . There were no differences between percentage correct on Days 3 and 5 ; thus, overall (Days 3 and 5 combined) data for percentage correct are presented.

\section{Inhibitory Avoidance}

The step-through inhibitory avoidance procedure assessed nonspatial/nonmotor-dependent memory (Frye \& McCormick, 2000; O'Connell, Earley, \& Leonard, 1994; Venault et al., 1986). The apparatus consisted of a two-compartment $(24 \times 18 \times 19 \mathrm{~cm}$ each) stainless steel box similar to that described by Venault et al. One chamber was brightly lit from above and painted white. The other was painted black and covered to block out light. The two chambers were separated by a guillotine door.

Habituation and training (Day 1): The rats were placed in the white room with the door down for $5 \mathrm{sec}$. The door was raised as soon as the rats were facing it, and the rats were then allowed to explore the entire box for $2 \mathrm{~min}$. Twenty minutes later, the rats were placed in the white chamber for $5 \mathrm{sec}$ or until they faced the door.
When the door was lifted, the rats entered the black compartment, and the door was closed behind them. The rats then received a mild shock ( $0.25 \mathrm{~mA}, 2-\mathrm{sec}$ duration). There were no differences between groups in the latency to the dark side on the training day (average latency was $69.5 \pm 30.6 \mathrm{sec}$ ). Following training, the rats were immediately removed and injected with a given dose of $P$, DHP, or $3 \alpha, 5 \alpha$-THP $(0.0,4.0$, or $8.0 \mathrm{mg} / \mathrm{kg}$, s.c. $)$.

Testing (Day 2): Twenty-four hours later, the rats were placed in the white chamber. The door was lifted, and the latency to enter the dark chamber was recorded ( $180 \mathrm{sec}$, maximum).

One-way ANOVAs, followed by Student Newman-Keuls post hoc tests, were used to determine differences in latency for animals injected with $0.0,4.0$, and $8.0 \mathrm{mg} / \mathrm{kg} \mathrm{P}$, DHP, or $3 \alpha, 5 \alpha$-THP.

\section{Object Recognition}

In the object recognition task (Frye \& Lacey, 1999; McCormick, McNamara, Mukhopadhyay, \& Kelsey, 1997), the rats were tested $24 \mathrm{~h}$ after injection for their memory of a familiar object, as measured by the amount of time spent within one body length of a new object. The object recognition box was $70 \mathrm{~cm}$ wide $\times 70 \mathrm{~cm}$ long, with two objects placed $30 \mathrm{~cm}$ apart in the center of the box. The objects used on Day 1 were curved pieces of metal pipe open at one end. The novel object used was a plastic, T-shaped pipe open at two ends.

Habituation and training (Day 1): The rats were placed individually in the object recognition box without the objects in it and were allowed to explore for $2 \mathrm{~min}$. Twenty minutes later, the rats were placed in the object recognition box with the two identical objects for $3 \mathrm{~min}$. There were no significant baseline differences among groups in the open-field behavior or investigation of objects. Following training, the rats were injected with $\mathrm{P}, \mathrm{DHP}$, or $3 \alpha, 5 \alpha-\mathrm{THP}$ $(0.0,4.0$, or $8.0 \mathrm{mg} / \mathrm{kg})$.

Testing (Day 2): The rats were placed in the box with one of the objects from Day 1 and one new object. Proximity to both objects was recorded for $3 \mathrm{~min}$.

A one-way ANOVA determined the effects of P, DHP, or $3 \alpha, 5 \alpha$ THP $(0.0,4.0$, and $8.0 \mathrm{mg} / \mathrm{kg})$ on time spent with the novel object (as a percentage of the total time spent with both objects).

\section{Open Field}

The open-field task was used as a measure of anxiety and motor activity (Blizard, Lipman, \& Chen, 1975; Frye et al., 2000; McCarthy, Felzenberg, Robbins, Pfaff, \& Schwartz-Giblin, 1995). The open field was a box, $57 \mathrm{~cm}$ wide $\times 76 \mathrm{~cm}$ long, with a 48 -square grid floor $(6 \times 8$ squares, $9.5 \mathrm{~cm} / \mathrm{side})$ and an overhead light illuminating the central squares (all but the perimeter squares were considered central). The rats were injected with $\mathrm{P}, \mathrm{DHP}$, or $3 \alpha, 5 \alpha-$ THP $(0.0,4.0$, or $8.0 \mathrm{mg} / \mathrm{kg}$, s.c. $)$, placed in the box, and observed for $5 \mathrm{~min}, 1 \mathrm{~h}$, and $24 \mathrm{~h}$ postinjection. The ratio of central squares entered to total number of entries into any square was used as an index of anxiety. An entry into a square was considered when all four paws were in the square. The total number of squares entered was considered an index of overall motor activity. One-way ANOVAs. followed by SNK post hoc tests, examined the effects of $P, D H P$, or $3 \alpha, 5 \alpha$-THP $(0.0,4.0$, or $8.0 \mathrm{mg} / \mathrm{kg})$ on the central versus total square entries ratio and total square entries 1 and $24 \mathrm{~h}$ postinjection.

\section{Elevated Plus-Maze}

The elevated plus-maze paradigm (Dunn, Reed, Copeland, \& Frye, 1998; Frye et al., 2000; Pellow \& File, 1986) was used to measure anxiety in the rats. The elevated plus-maze consisted of four arms $10 \mathrm{~cm}$ wide elevated $50 \mathrm{~cm}$ off the ground. Two arms were enclosed by walls $30 \mathrm{~cm}$ high, and the other two arms were exposed. The rats were placed at the junction of the open and the closed arms of the maze and were observed for $5 \mathrm{~min}$. The amount of time spent on the open arms was recorded 1 and $24 \mathrm{~h}$ after injection of $\mathrm{P}$, DHP, or $3 \alpha, 5 \alpha$-THP $(0.0,4.0$, and $8.0 \mathrm{mg} / \mathrm{kg}$, s.c.). One-way ANOVAs, followed by SNK post hoc tests, examined the effects of P, DHP, or 
$3 \alpha, 5 \alpha$-THP on anxiety, as measured by time spent in the open arms, 1 and $24 \mathrm{~h}$ postinjection.

\section{Tailflick}

The tailflick paradigm (D'Amour \& Smith, 1941; Frye \& Duncan, 1994, 1995) was used to test the effects of P, DHP, or $3 \alpha, 5 \alpha-$ THP on pain sensitivity. The rats were handled, covered with a towel, placed on the platform of the tailflick apparatus (San Diego Instruments), and held in place as their tails were smoothed above the radiant heat source. The mean latency of three tailflick trials, 1 and $24 \mathrm{~h}$ after P, DHP, or $3 \alpha, 5 \alpha$-THP, was used as an index of nociception. One-way ANOVAs examined differences on the latency measure between $0.0,4.0$, and $8.0 \mathrm{mg} / \mathrm{kg} \mathrm{l}$ and at $24 \mathrm{~h}$ postinjection with P, DHP, or $3 \alpha, 5 \alpha$-THP.

\section{Steroid Hormone Measurements}

Following behavioral testing, the rats were readministered their assigned milieu of P, DHP, or $3 \alpha, 5 \alpha$-THP $(0.0,4.0$, or $8.0 \mathrm{mg} / \mathrm{kg})$, and blood was collected from the tail vein 1 and $24 \mathrm{~h}$ later. Plasma samples were extracted with diethyl ether, reconstituted in phosphate assay buffer $(\mathrm{PH}=7.4)$, equilibrated, and analyzed by radioimmunoassay ( $P$ antibody: Endocrine Sciences, P1 1-192, 1:30,000 dilution; DHP and $3 \alpha, 5 \alpha$-THP: Dr. Robert Purdy, X947 and X1412, respectively, 1: 5,000 dilutions) to determine the circulating concentrations produced by the steroids administered.

\section{RESULTS}

\section{Y-maze}

$\mathrm{P}(4.0 \mathrm{mg} / \mathrm{kg})$ significantly $[F(2,21)=4.48, p<.05] \mathrm{re}-$ duced latencies to the goal box on Trials $1-5$ of Day 5 (see Figure 1) but did not affect percentage of correct choices.

DHP $(4.0$ and $8.0 \mathrm{mg} / \mathrm{kg})$ significantly $[F(2,21]=6.84$, $p<.01]$ reduced latencies to the goal arm on Trials $1-5$ of Day 5 . Only the $8.0 \mathrm{mg} / \mathrm{kg}$ group had significantly lower latencies than the controls on Trials 6-10 on Day 5 $[F(2,21)=3.60, p<.05$; see Figure 1]. DHP significantly $[F(2,21)=3.53, p<.05]$ increased the percentage of correct choices overall for the 4.0 and $8.0 \mathrm{mg} / \mathrm{kg}$ groups, as compared with the controls (see Figure 2).

$3 \alpha, 5 \alpha$-THP did not affect the latency or percent correct measure in the Y-maze.

\section{Inhibitory Avoidance}

Administration of $\mathrm{P}[4.0$ and $8.0 \mathrm{mg} / \mathrm{kg} ; F(2,21)=$ $3.33, p<.05$ ], DHP [ 4.0 and $8.0 \mathrm{mg} / \mathrm{kg} ; F(2,21)=4.62$, $p<.05]$, or $3 \alpha, 5 \alpha$-THP [8.0 mg $/ \mathrm{kg} ; F(2,21)=3.31, p<$ $.05]$ significantly increased the latency to enter the dark chamber in the inhibitory avoidance task, as compared with vehicle administration (see Figure 3 ).

\section{Object Recognition}

$\mathbf{P}(8.0 \mathrm{mg} / \mathrm{kg})$ significantly increased $[F(2,21)=3.75$, $p<.05]$ the percentage of time with the novel object, as compared with that seen following vehicle administration (see Figure 4); however, DHP and $3 \alpha, 5 \alpha$-THP did not significantly influence the amount of time spent with a novel object.

\section{Open Field}

$\mathrm{P}[4.0$ and $8.0 \mathrm{mg} / \mathrm{kg} ; F(2,36)=8.80, p<.01]$, DHP $[4.0 \mathrm{mg} / \mathrm{kg} ; F(2,36)=4.78, p<.05]$, and $3 \alpha, 5 \alpha$-THP
$[4.0 \mathrm{mg} / \mathrm{kg} ; F(2,36)=5.85, p<.01]$, when administered $1 \mathrm{~h}$, but not $24 \mathrm{~h}$, prior to testing, significantly increased the number of entries into central squares (see Figure 5). There was no effect on the total squares entered for any of the progestins.

\section{Elevated Plus-Maze}

$\mathrm{P}[4.0$ or $8.0 \mathrm{mg} / \mathrm{kg} ; F(2,21)=7.97, p<.05]$, DHP $[4.0$ or $8.0 \mathrm{mg} / \mathrm{kg} ; F(2,21)=7.63, p<.05]$, and $3 \alpha, 5 \alpha-$ THP [ 4.0 or $8.0 \mathrm{mg} / \mathrm{kg} ; F(2,21)=11.57, p<.05]$ significantly increased time spent on the open arms $1 \mathrm{~h}$, but not 24 h, postinjection (see Figure 6).

\section{Tailflick}

$\mathrm{P}[4.0$ and $8.0 \mathrm{mg} / \mathrm{kg} ; F(2,21)=7.40, p<.01]$, DHP [ 4.0 and $8.0 \mathrm{mg} / \mathrm{kg} ; F(2,21)=3.70, p<.05$ ], and $3 \alpha, 5 \alpha$ THP $[8.0 \mathrm{mg} / \mathrm{kg} ; F(2,21)=6.14, p<.01]$, when administered $1 \mathrm{~h}$, but not $24 \mathrm{~h}$, prior to testing, caused significantly longer latencies to tailflick when compared with controls (see Figure 7).

\section{Steroid Hormone Measurements}

Progestin concentrations following 4.0 and $8.0 \mathrm{mg} / \mathrm{kg}$ were significantly increased over control $0.0 \mathrm{mg} / \mathrm{kg}$ values $1 \mathrm{~h}$, but not $24 \mathrm{~h}$, following $\mathrm{P}[F(2,42)=330.68, p<$ $.01]$, DHP $[F(2,42)=57.67, p<.01]$, or $3 \alpha, 5 \alpha$-THP $[F(2,42)=18.25, p<.01]$ administration. P concentrations $1 \mathrm{~h}$ following 4.0 or $8.0 \mathrm{mg} / \mathrm{kg}$ were $1.9 \pm 0.3$ and $4.6 \pm 1.1 \mathrm{ng} / \mathrm{ml} ; 24 \mathrm{~h}$ following $\mathrm{P}(4.0$ or $8.0 \mathrm{mg} / \mathrm{kg})$ and 1 or $24 \mathrm{~h}$ following vehicle control, concentrations were $0.2 \pm 0.03 \mathrm{ng} / \mathrm{ml}$. Plasma $P$ across the estrous cycle has been reported to range from $5-10 \mathrm{ng} / \mathrm{ml}$ on diestrus up to 20-40 ng/ml on proestrus (Belanger, Cusan, Barden, \& Dupont, 1981; Butcher, Collins, \& Fugo, 1974).

DHP concentrations $1 \mathrm{~h}$ following 4.0 or $8.0 \mathrm{mg} / \mathrm{kg}$ were $19.7 \pm 0.5$ and $31.6 \pm 0.4 \mathrm{ng} / \mathrm{ml} ; 24 \mathrm{~h}$ following DHP (4.0 or $8.0 \mathrm{mg} / \mathrm{kg})$ and 1 or $24 \mathrm{~h}$ following vehicle control, concentrations were $7.2 \pm 1.1 \mathrm{ng} / \mathrm{ml}$. Plasma DHP is approximately $3 \mathrm{ng} / \mathrm{ml}$ in intact rats and ranges from 4 to $44 \mathrm{ng} / \mathrm{ml}$ during pregnancy (Corpechot et al., 1993; Sanyal, 1978).

Concentrations of $3 \alpha, 5 \alpha$-THP $1 \mathrm{~h}$ following 4.0 or $8.0 \mathrm{mg} / \mathrm{kg}$ were $3.8 \pm 0.3$ and $8.5 \pm 0.3 \mathrm{ng} / \mathrm{ml} ; 24 \mathrm{~h}$ following $3 \alpha, 5 \alpha$-THP $(4.0$ or $8.0 \mathrm{mg} / \mathrm{kg})$ and 1 or $24 \mathrm{~h}$ following vehicle control, concentrations were $1.2 \pm$ $0.2 \mathrm{ng} / \mathrm{ml}$. Plasma levels of $3 \alpha, 5 \alpha$-THP have been shown to range from approximately $2 \mathrm{ng} / \mathrm{ml}$ on diestrus to $8 \mathrm{ng} / \mathrm{ml}$ on proestrus (Frye \& Bayon, 1999; Purdy, Morrow, Blinn, \& Paul, 1990).

\section{DISCUSSION}

Progesterone, DHP, and $3 \alpha, 5 \alpha$-THP had different effects on cognitive performance but produced similar outcomes on affective tasks. $P$ reduced latencies to the goal arm in the Y-maze, enhanced retention intervals in the inhibitory avoidance task, and increased the percentage of time with a novel object. DHP reduced latencies to the goal arm, increased the percentage of correct choices in 

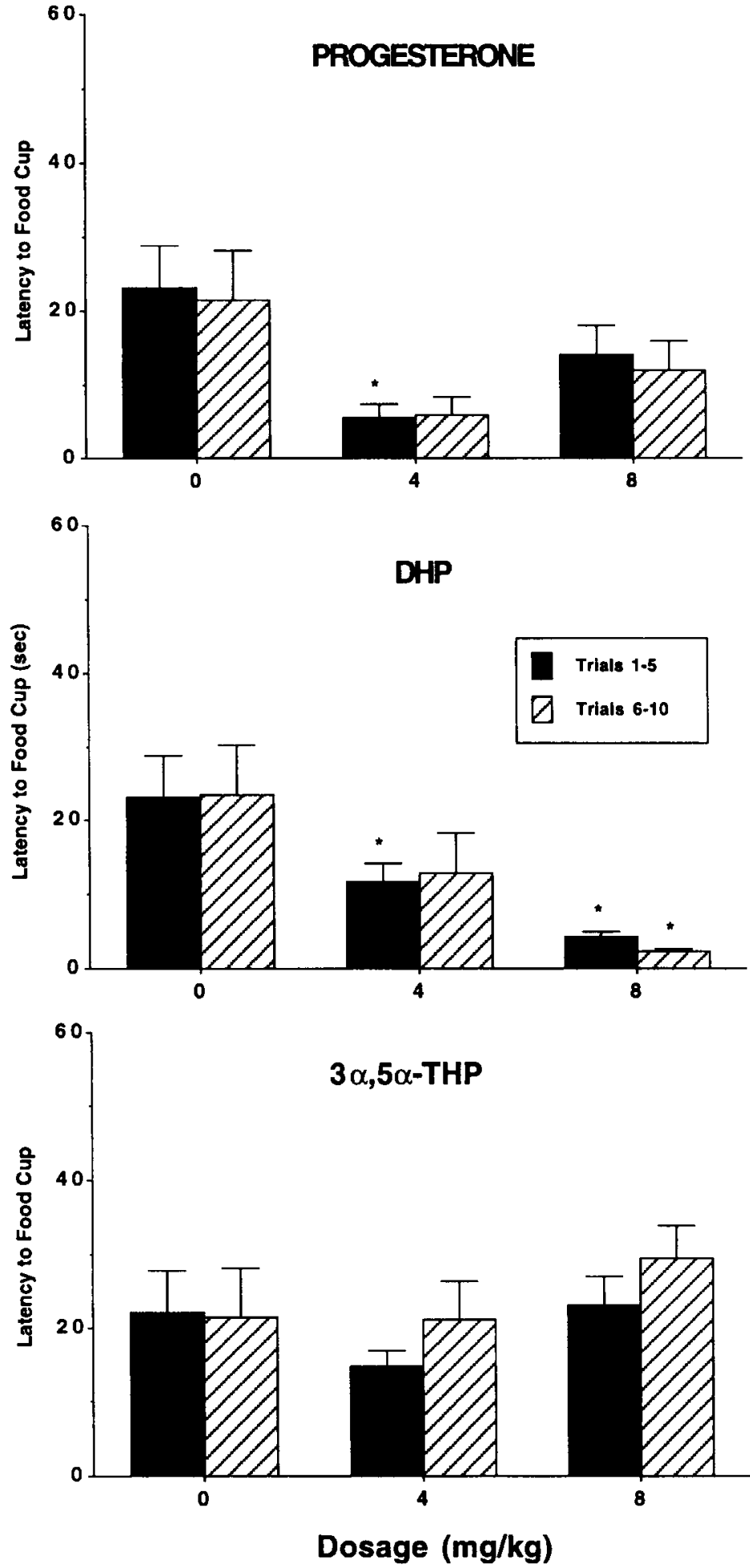

Figure 1. Mean latencies to the food cup ( $\pm S E M)$ for progesterone (P; top), dihydroprogesterone (DHP; middle), and $3 \alpha, 5 \alpha$-THP (bottom) on Day 5 of the Y-maze. P (4.0 mg/kg) significantly decreased latencies on Trials 1-5 (solid bars), as compared with $8.0 \mathrm{mg} / \mathrm{kg}$ and controls. DHP (4.0 and $8.0 \mathrm{mg} / \mathrm{kg}$ ) significantly decreased latencies on Trials $1-5.8 .0 \mathrm{mg} / \mathrm{kg}$ significantly decreased latencies on Trials 6-10 (striped bars). $3 \alpha, 5 \alpha$-THP had no effect. 

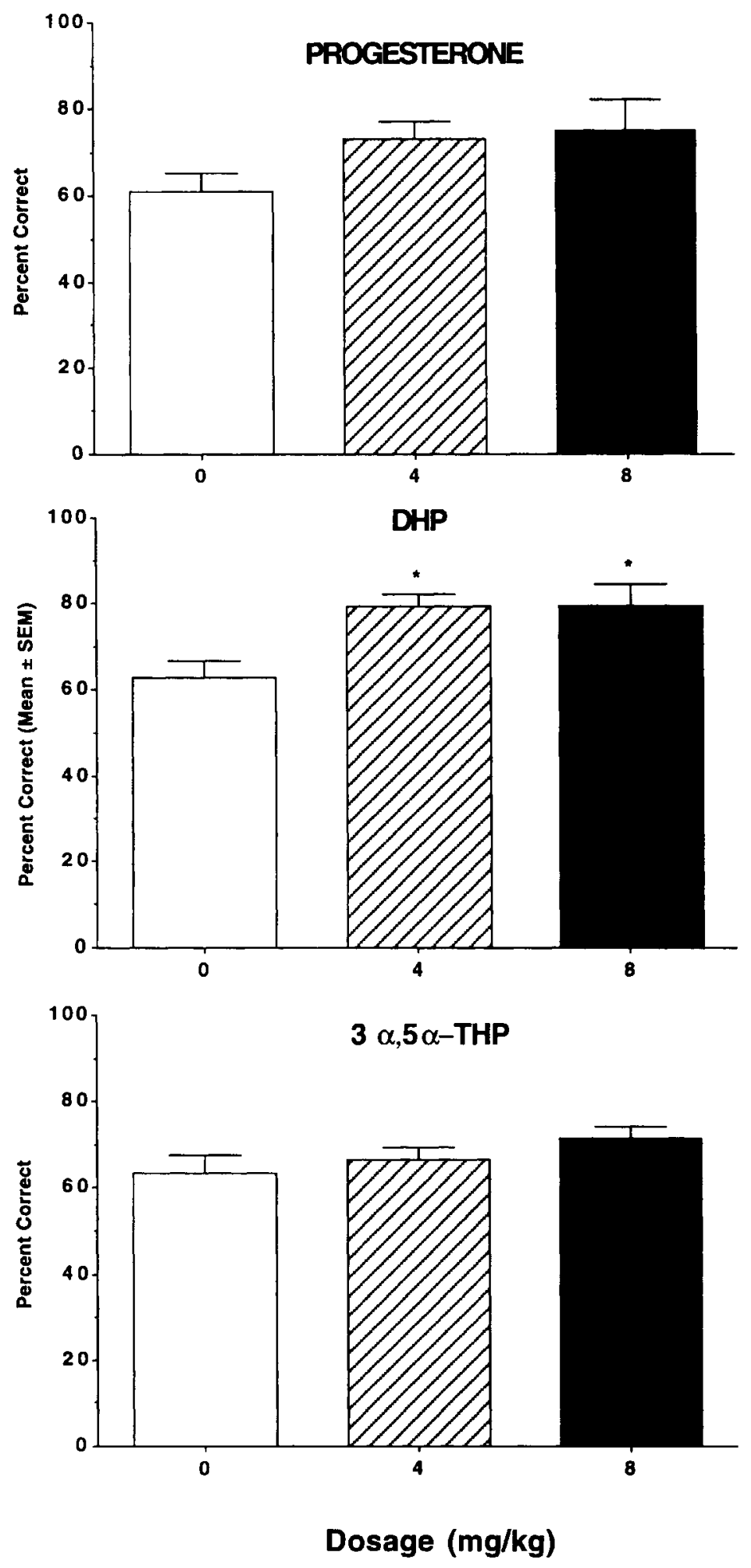

Figure 2. Overall percentage of correct arm entries $( \pm S E M)$ for progesterone (P; top), dihydroprogesterone (DHP; middle), and $3 \alpha, 5 \alpha$-THP (bottom) in the Y-maze. DHP (4.0 mg/kg, striped bars, and $8.0 \mathrm{mg} / \mathrm{kg}$, solid bars) significantly increased the percentage of correct arm entries, as compared with controls (white bars). P and $3 \alpha, 5 \alpha$-THP did not affect this measure. 

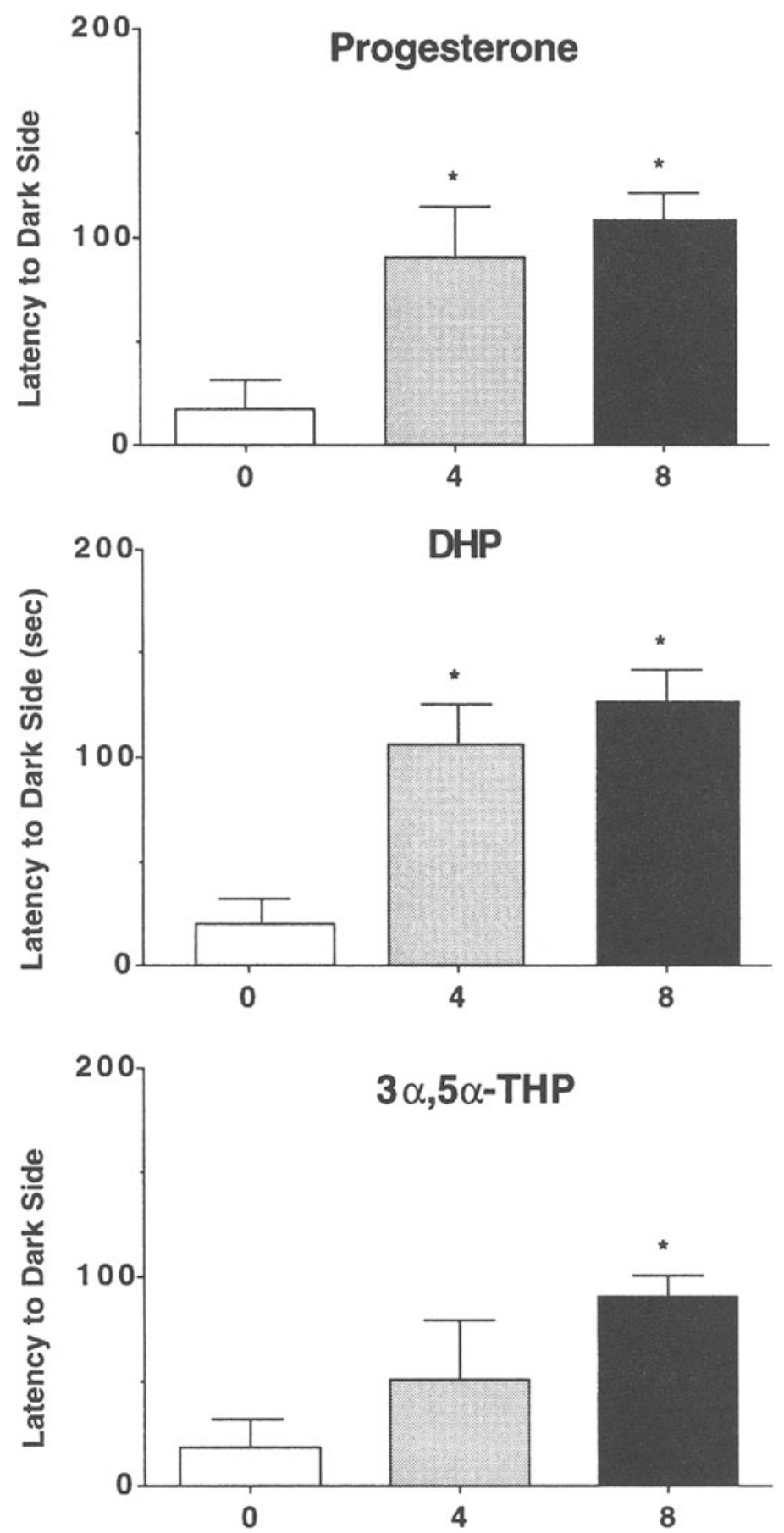

Figure 3. Latency to the dark, shock-associated side of the inhibitory avoidance chamber $( \pm S E M)$ for progesterone (P; top), dihydroprogesterone (DHP; middle), and $3 \alpha, 5 \alpha$-THP (bottom). P (4.0 mg/kg, gray bars, and $8.0 \mathrm{mg} / \mathrm{kg}$, black bars), DHP (4.0 mg/kg, gray bars, and $8.0 \mathrm{mg} / \mathrm{kg}$, black bars), and $3 \alpha, 5 \alpha$-THP (8.0 mg/kg, black bars) significantly increased crossover latencies, as compared with controls (white bars). 

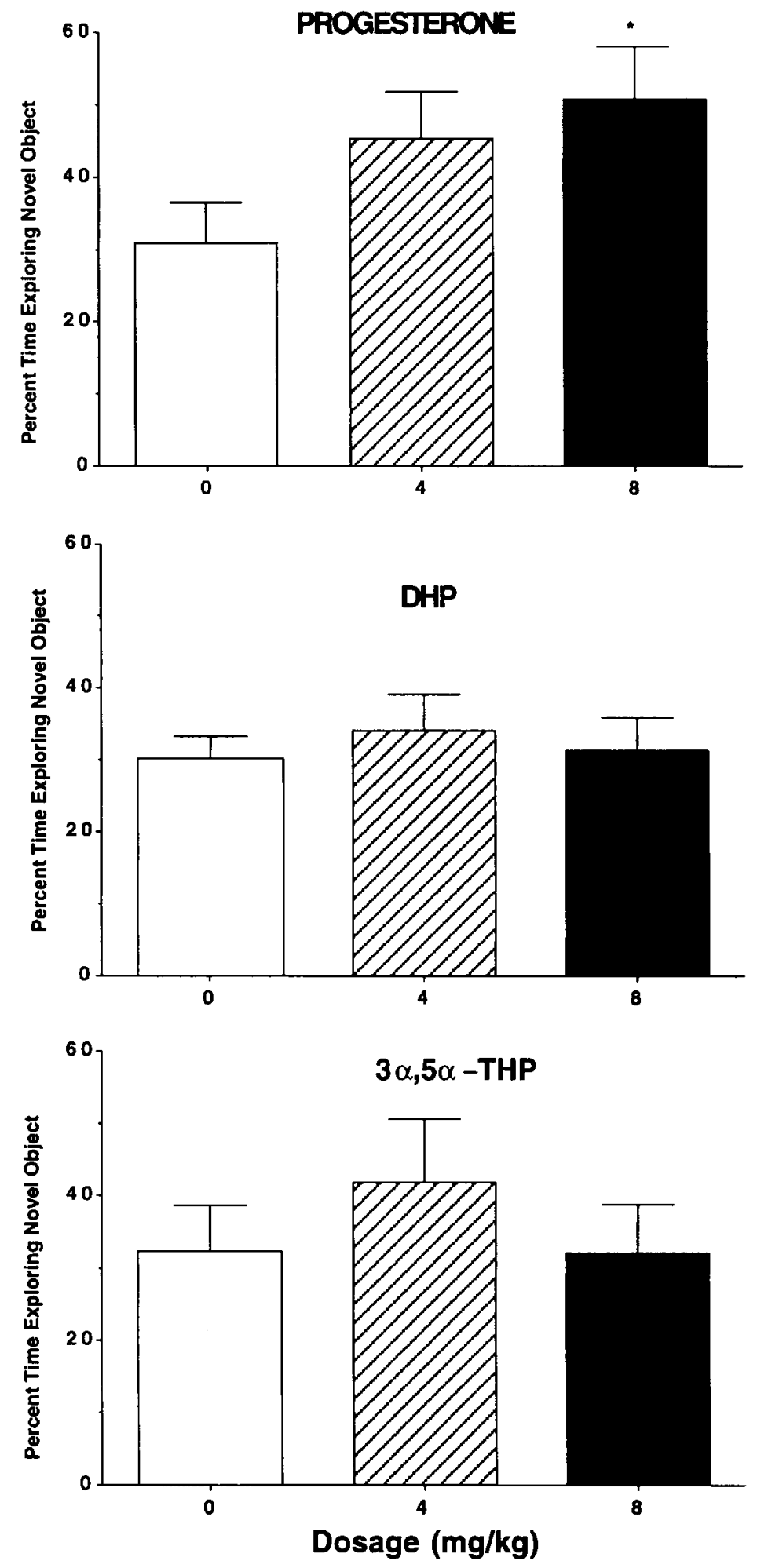

Figure 4. Percentage of time exploring a novel object $( \pm S E M)$ for progesterone (P; top), dihydroprogesterone (DHP; middle), and $3 \alpha, 5 \alpha$-THP (bottom) in the object recognition task. $P(8.0 \mathrm{mg} / \mathrm{kg}$, solid bar) significantly increased the percentage of time spent exploring a novel object, as compared with controls (white bar). DHP and $3 \alpha, 5 \alpha$-THP did not affect this measure. 

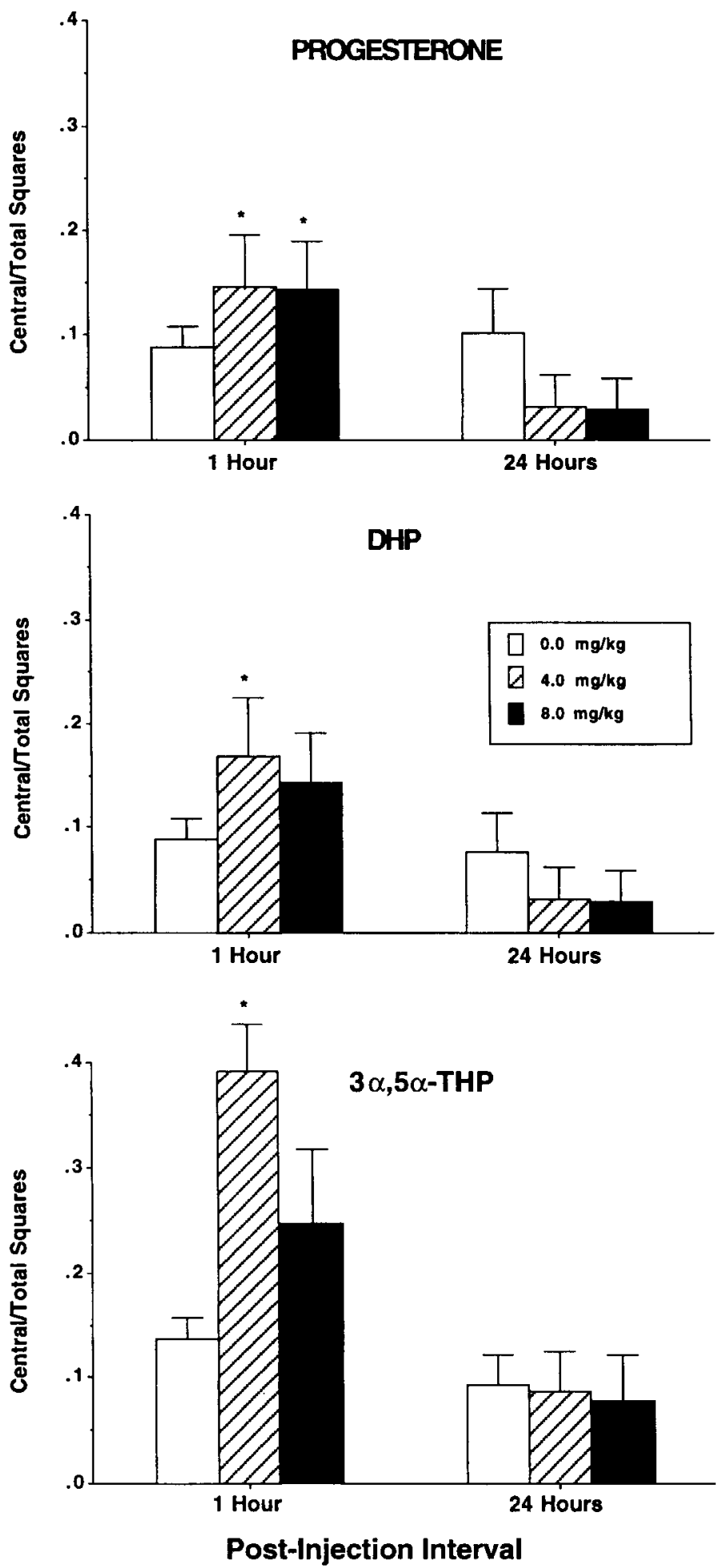

Figure 5. Ratio of central to total squares entered in the open field ( $\pm S E M) 1$ and 24 h following progesterone (P; top), dihydroprogesterone (DHP; middle), or $3 \alpha, 5 \alpha$-THP (bottom). P (4.0 mg/kg, striped bars, and $8.0 \mathrm{mg} / \mathrm{kg}$, solid bars), DHP $(4.0 \mathrm{mg} / \mathrm{kg})$, and $3 \alpha, 5 \alpha$-THP $(4.0 \mathrm{mg} / \mathrm{kg})$ significantly increased the ratio of central to total squares $1 \mathrm{~h}$ after injection. Twenty-four hours after injection, there were no differences between the three dosages of P, DHP, or $3 \alpha, 5 \alpha$-THP. 

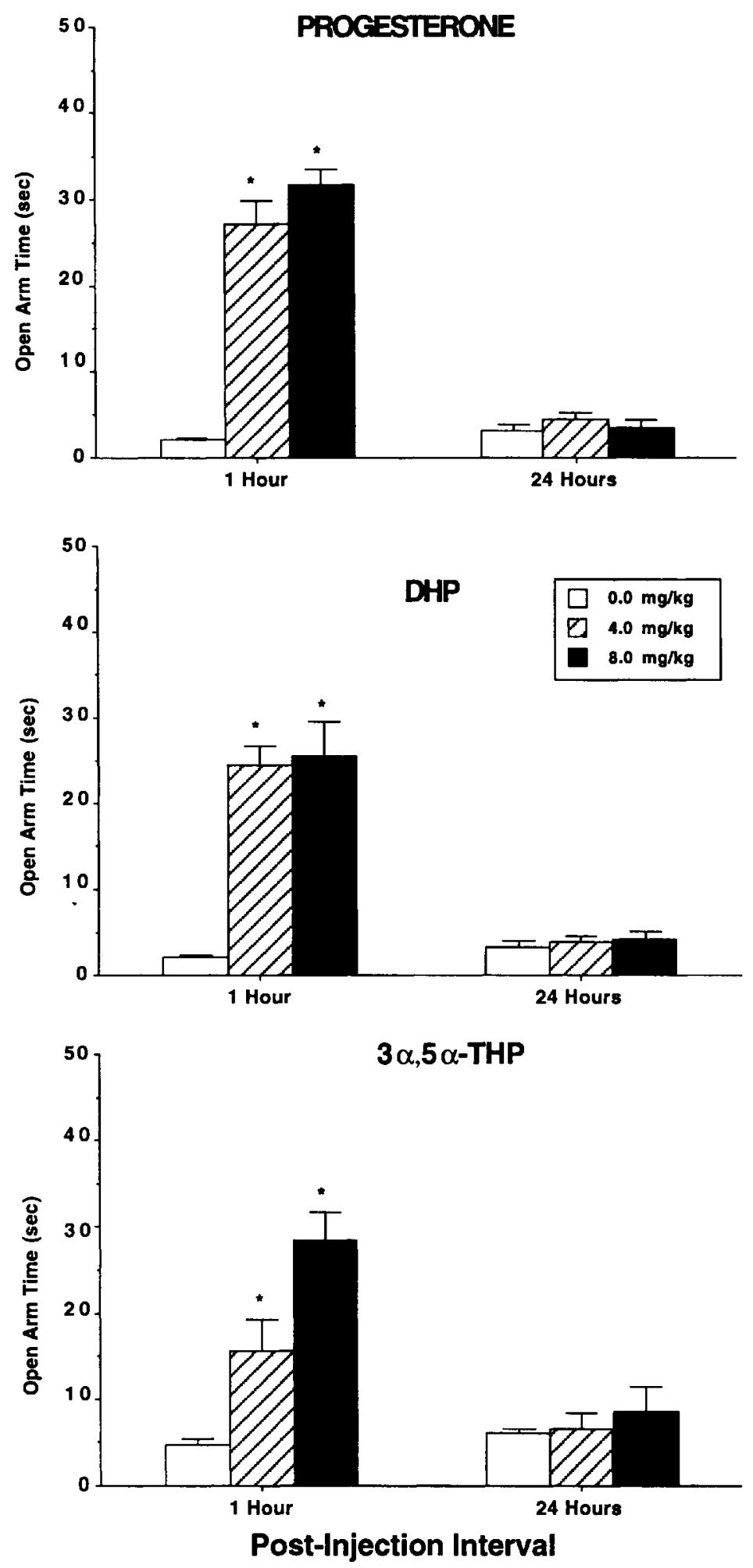

Figure 6. Open arm time in the elevated plus maze ( $\pm S E M) 1$ and $24 \mathrm{~h}$ following progesterone (P; top), dihydroprogesterone (DHP; middle), or $3 \alpha, 5 \alpha$ THP (bottom). P (4.0 mg/kg, striped bars, and $8.0 \mathrm{mg} / \mathrm{kg}$, solid bars), DHP (4.0 and $8.0 \mathrm{mg} / \mathrm{kg}$ ), and $3 \alpha, 5 \alpha$-THP (4.0 and $8.0 \mathrm{mg} / \mathrm{kg}$ ) significantly increased the open arm time $1 \mathrm{~h}$ after injection, as compared with vehicle administration (white bars). Twenty-four hours after injection, there were no differences between the three dosages of P, DHP, or $3 \alpha, 5 \alpha$-THP. 

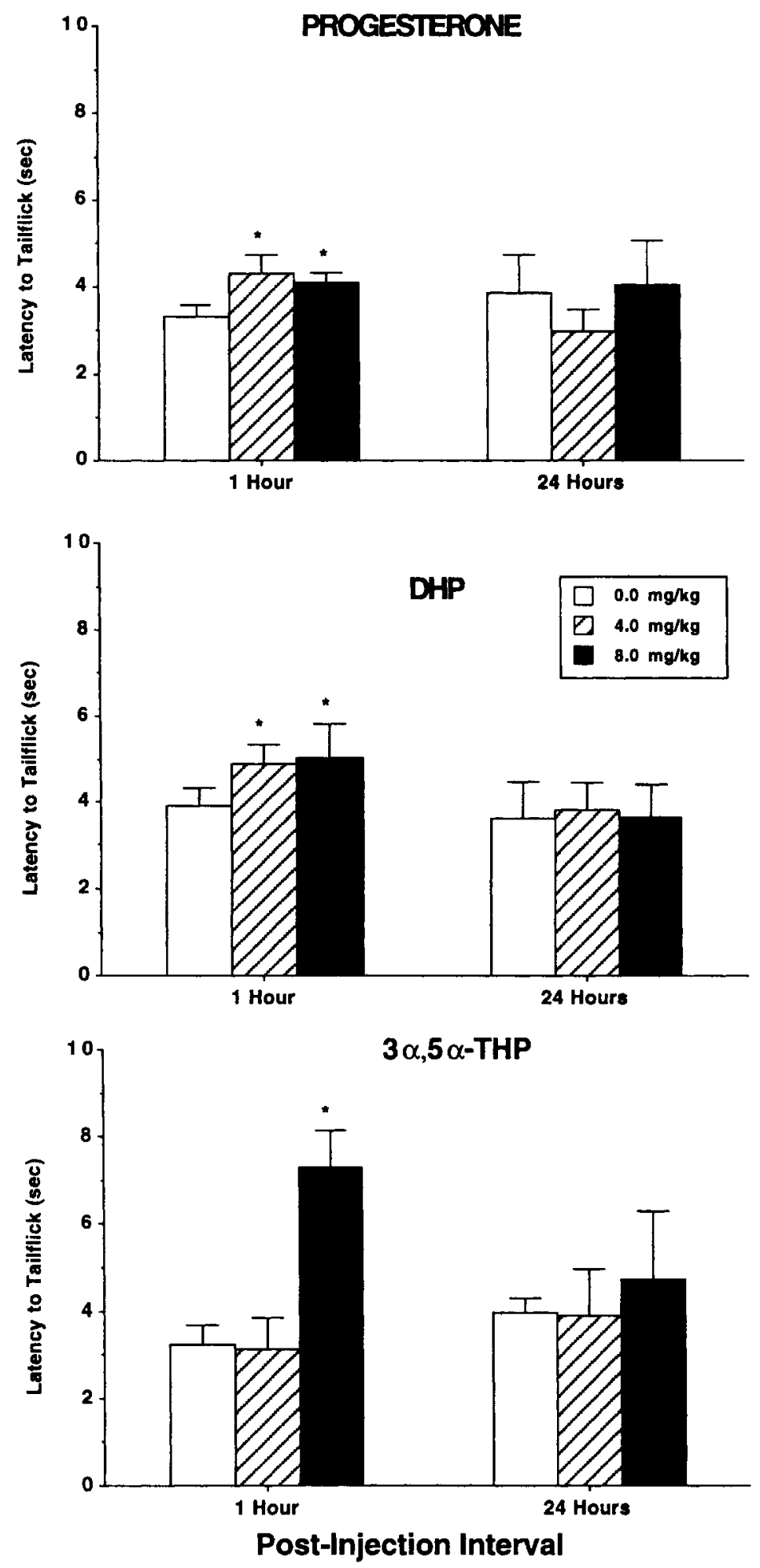

Figure 7. Latency to tailfick ( $\pm S E M$ ) 1 and $24 \mathrm{~h}$ following progesterone (P; top), dihydroprogesterone (DHP; middle), or $3 \alpha, 5 \alpha$-THP (bottom). P (4.0 mg/kg, striped bars, and $8.0 \mathrm{mg} / \mathrm{kg}$, solid bars), DHP (4.0 and $8.0 \mathrm{mg} /$ $\mathrm{kg})$, and $3 \alpha, 5 \alpha-$ THP $(8.0 \mathrm{mg} / \mathrm{kg})$ significantly increased the latency to tailflick 1 h after injection, as compared with controls (white bars). Twentyfour hours after injection, there were no differences between the dosages for any of the steroids. 
the Y-maze, and enhanced inhibitory avoidance. In the inhibitory avoidance task, $3 \alpha, 5 \alpha$-THP improved latencies but did not have any other effects on performance in these cognitive tasks.

Previous research has shown that progestins can have differential effects on cognitive performance. Long-term potentiation (LTP) varies over the estrous cycle (Warren, Humphreys, Juraska, \& Greenough, 1995), and progestins can modulate hippocampal electrophysiological responses (although not LTP or excitatory postsynaptic potentials directly; Landgren, 1991). Also, systemic administration of $\mathrm{P}(500 \mu \mathrm{g}$, s.c. $), 19$-norprogesterone, hydroxydione, corticosterone, deoxycorticosterone, cortisone, or hydrocortisone results in impaired performance in passive avoidance behavior (Hamburg, 1966; van Wimersma Greidanus, 1977) when administered prior to testing. Lower ( 3.2 and $6.4 \mathrm{mg} / \mathrm{kg}$ ) systemic dosages of $3 \alpha, 5 \alpha$-THP, when administered just prior to testing, reduce latencies and distances to the platform in a Morris water maze task, whereas the same dosages of other neurosteroids, pregnenolone sulfate (PS) and dehydroepiandrosterone (DHEAS), impair performance. $3 \alpha, 5 \alpha$-THP $(6.4 \mathrm{mg} / \mathrm{kg}$ and ICV implants) increases latencies and decreases percentage of correct choices in the Y-maze, whereas $6.4 \mathrm{mg} / \mathrm{kg}$ s.c. and ICV implants of other neurosteroids, DHEAS and PS, have the opposite effect (Frye \& Sturgis, 1995). These aforementioned pregnane- and neurosteroid-induced decrements in cognitive performance have been attributed to the steroids' reducing animals' sensitivity to arousing or aversive stimuli (Bitran et al., 1991 a, 199lb; Frye \& Duncan, 1994, 1995), through their actions at GBRs (biphasic dosage effects were attributed to allosteric modulation of GBRs). Indeed, $3 \alpha, 5 \alpha-$ THP is devoid of affinity for intracellular progestin receptors but enhances GABA-mediated chloride currents, whereas DHEA and PS display functional antagonistic properties at GBRs (Rupprecht, 1997).

The present experiments confirm and extend the notion that progestins may have effects on cognitive performance. Although the timing of these effects did not coincide with overt alterations in affective behaviors (such as those seen $\mathrm{l} \mathrm{h}$ following progestin administration), there are a number of reasons it may be premature to conclude that the cognitive effects observed were not due to the altered affective state of the animals. First, P, DHP, and $3 \alpha, 5 \alpha$-THP did produce analgesic and anxiolytic effects when administered $1 \mathrm{~h}$ prior to open-field, plus-maze, or tailflick testing. The analgesic and anxiolytic effects of $P$, DHP, and $3 \alpha, 5 \alpha$-THP were no longer apparent $24 \mathrm{~h}$ following progestin administration, when initial cognitive testing was conducted. According to our findings from the open-field, plus-maze, and tailflick tasks, effects of the progestins in cognitive tasks may not be due to their overt anxiety-reducing side effects. However, effects of the progestins on cognitive performance could be due to the anxiogenic effects resulting from $\mathrm{P}$ or $3 \alpha, 5 \alpha$-THP withdrawal (Frye, Scalise, \& Bayon, 1998; Gallo \& Smith, 1993; Smith et al., 1998). Second, performance in some affective tasks can be highly confounded by retesting, especially within $24 \mathrm{~h}$. Hence, one cannot rule out the possibility that the lack of effect of progestins at the 24-h tests of anxiety are due to test decay. Finally, additional experiments testing cognitive and anxiety measures at both 1 and $24 \mathrm{~h}$ postinjection would allow a more clear-cut conclusion concerning the contribution of anxiety in cognitive performance.

Although the exact physiological (genomic vs. nongenomic) or mnemonic (acquisition, consolidation, or retention) mechanisms through which progestins affect cognition are not yet defined, the present data confirm and expand upon earlier reports of the effects of progestins on cognitive and affective function. These and additional data from future animal studies may extend the burgeoning literature on the cognitive effects of progestins and help elucidate the manner in which $P$ mitigates the beneficial effects of E on mood (Rice, Graves, McCurry, \& Larson, 1997), enhances dream recall (Sheldrake \& Cormack, 1974, 1976), or impairs retrieval of learned information coincident with intact encoding in women with PMS (Keenan, Lindamer, \& Jong, 1995).

\section{REFERENCES}

Aggleton, J. P., Blindt, H. S., \& Candy, J. M. (1989). Working memory in aged rats. Behavioral Neuroscience, 103, 975-983.

Ator, N. A., Grant, K. A., Purdy, R. H., Paul, S. M., \& Griffiths, R. R. (1993). Drug discrimination analysis of endogenous neuroactive steroids in rats. European Journal of Pharmacology, 241, 237-243.

Belanger, A., Cusan, L., Barden, L., \& Dupont, A. (1981). Ovarian progestins, androgens and estrogen throughout the 4-day estrous cycle in the rat. Biology of Reproduction, 24, 591-596.

Berman, K. F., Schmidt, P. J., Rubinow, D. R., Danaceau, M. A., van HorN, J. D., EsPosito, G., Ostrem, J., \& Weingerger, D. R. (1997). Modulation of cognitive specific cortical activity by gonadal steroids: A positron-emission tomography study in women. Proceedings of the National Academy of Sciences, 94, 8836-8841.

Bitran, D., Hilvers, R. J., \& Kellogg, C. K. (1991a). Anxiolytic effects of $3 \alpha$-hydroxy- $5 \alpha, \beta$-pregnan-20-one endogenous metabolites of progesterone that are active at the $\mathrm{GABA}_{\mathrm{A}}$ receptor. Brain Research, 561, 157-161.

Bitran, D., Hilvers, R. J., \& Kellogg, C. K. (1991b). Ovarian endocrine status modulates the anxiolytic potency of diazepam and the efficacy of GABA-benzodiazepine receptor-mediated chloride ion transport. Behavioral Neuroscience, 105, 653-662.

Bitran, D., Shiekh, M., \& McLeod, M. (1995). Anxiolytic effect of progesterone is mediated by the neurosteroid allopregnanolone at brain GABA ${ }_{A}$ receptors. Journal of Neuroendocrinology, 7, 171-177.

Blizard, D. A., Lipman, H. R., \& CheN, J. J. (1975). Sex differences in open-field behavior in the rat: The inductive and activational role of gonadal hormones. Physiology \& Behavior, 14, 601-608.

Brindle, P. M., Brown, M. W., Brown, J., Griffith, H. B., \& TURNER, G. (1991). Objective and subjective memory impairment in normal human pregnancy. Psychological Medicine, 21, 647-653.

Broverman, D. M., Vogel, W., Klaiber, E. L., Majcher, D., ShEa, D., \& Paul, V. (1981). Changes in cognitive task performance across the menstrual cycle. Journal of Comparative \& Physiological Psychology, 95, 646-654.

Butcher, R. L., Collins, W. E., \& Fugo, N. W. (1974). Plasma concentrations of LH, FSH, prolactin, progesterone and estradiol throughout the 4-day estrous cycle of the rat. Endocrinology, 94, 1704-1708

Cheng, Y. J., \& Karavolas, H. J. (1973). Conversion of progesterone to $5 \alpha$-pregnane-3,20-dione and $3 \alpha$-hydroxy-5 $\alpha$-pregnan-20-one by 
rat medial basal hypothalamus and the effects of stage of the estrous cycle on the conversion. Endocrinology, 93, 1157-1162.

Corpechot, C., Young, J., Calvel, M., Wehrey, C., Veltz, J. N., Touyer, G., Mouren, M., Prasad, V. V. K., Banner, C., Suovall, J., Baulieu, E. E., \& Robel, P. (1993). Neurosteroids: $3 \alpha$-hydroxy- $5 \alpha$ pregnan-20-one and its precursors in the brain, plasma, and steroidogenic glands of male and female rats. Endocrinology, 133, 1003-1009.

D'Amour, F. E., \& Sмiтh, D. L. (1941). A method for determining loss of pain sensation. Journal of Pharmacology \& Experimental Therapeufics, 72, 74-79.

Diaz-Veliz, G., Urresta, F., Dussaubat, N., \& Mora, S. (1994). Progesterone effects on the acquisition of conditioned avoidance responses and other motoric behaviors in intact and ovariectomized rats. Psychoneuroendocrinology, 19, 387-394.

Dohanich, G. P., FAdER, A. J., \& Javorsky, D. J. (1994). Estrogen and estrogen progesterone treatments counteract the effect of scopolamine on reinforced T Maze alteration in female rats. Behavioral Neuroscience, 108, 988-992.

Dunn, R. W., Reed, T. A. W., Copeland, P. D., \& Frye, C. A. (1998). The nitric oxide synthase inhibitor 7-nitroindazole displays enhanced anxiolytic efficacy without tolerance in rats following subchronic administration. Neuropharmacology, 37, 899-904.

Ebner, D. L., Richardson, R., \& Riccio, D. C. (1981). Ovarian hormones and retention of learned fear in rats. Behavioral \& Neural Biology, 33, 45-58.

Eidelman, A. I., Hoffman, N. W., \& Kaitz, M. (1993). Cognitive deficits in women after childbirth. Obstetrics \& Gynecology, 81, 764767.

Frye, C. A.. \& BAYON, L. E. (1999). Mating stimuli influence endogenous variations in the neurosteroid $3 \alpha, 5 \alpha$-THP and $3 \alpha$-Diol. Journal of Neuroendocrinology, 11, 839-848.

Frye, C. A., Bayon, L. E., Pursnani, N., \& Purdy, R. H. (1998). Progesterone and allopregnanolone enhance proceptivity, receptivity, and sexual motivation of female rats. Brain Research, 808, 72-83.

Frye, C. A., \& Duncan, J. E. (1994). Progesterone metabolites, effective at the $\mathrm{GABA}_{\mathrm{A}}$ receptor complex, attenuate pain sensitivity in rats. Brain Research, 643, 194-203.

Frye, C. A., \& DunCan, J. E. (1995). Estradiol benzoate potentiates neuroactive steroids' effects on pain sensitivity. Pharmacology, Biochemistry \& Behavior, 53, 27-32.

Frye. C. A., \& Lacey, E. H. (1999). The neurosteroids DHEA and DHEAS may influence cognitive performance by altering affective state. Physiology \& Behavior, 66, 85-92.

Frye, C. A., \& MCCormick, C. M. (2000). The neurosteroid $3 \alpha-$ Androstanediol prevents inhibitory avoidance deficits and pyknotic cells in the granule layer of the dentate gyrus induced by adrenalectomy in rats. Brain Research, 855, 166-170.

Frye, C. A., Petralia, S. M.. \& Rhodes, M. E. (2000). Proestrous increases in exploratory behavior coincide with increases in progesterone and $3 \alpha, 5 \alpha$-THP. Pharmacology, Biochemistry \& Behavior, 67, $1-10$.

Frye. C. A., Scalise, T. J., \& Bayon, L. E. (1998). Finasteride blocks the reduction in ictal activity produced by exogenous estrous cyclicity. Journal of Neuroendocrinology, 10, 291-296.

FrYe, C. A., \& Sturgis, J. D. (1995). Neurosteroids affect spatial/reference, working and long-term memory of female rats. Behavioral \& Neural Biologv, 64, 83-96.

Gallo, M. A., \& Smith, S. S. (1993). Progesterone withdrawal decreases latency to and increases duration of electrified prod burial: $A$ possible rat model of PMS anxiety. Pharmacology, Biochemistry \& Behavior, 46, 897-904.

Hamburg, D. A. (1966). Effects of progesterone on behavior. In R. Levine (Ed.), Endocrines and the central nervous system (pp. 25I265). Baltimore: Williams \& Wilkins.

Harrison, N. L., Majewska, M. D., Harrington, J. W., \& Barker, J. L. (1987). Structure-activity relationships for steroid interaction with the gamma-aminobutyric acid A receptor complex. Journal of Pharmacology \& Experimental Therapeutics, 241, 346-353.

Heinsbroek, R. P. W.. van Haaren, F., Zantvoord, F., \& van de
POLL, N. E. (1987). Discriminative stimulus properties of pentobarbital and progesterone in male and female rats. Pharmacology, Biochemistry \& Behavior, 28, 371-374.

Iswari, S., Colas, A. E., \& Karavolas, H. J. (1986). Binding of $5 \alpha$ dihydroprogesterone and other progestins to female rat anterior pituitary nuclear extracts. Steroids, 47, 189-203.

Karavolas, H. J., \& Nuti, K. M. (1976). Progesterone metabolism by neuroendocrine tissues. In F. Naftolin, K. J. Ryan, \& J. Davies (Eds.), Subcellular mechanisms in reproductive neurnendocrinology (pp. 305326). Amsterdam: Elsevier.

Keenan, P. A., Lindamer, L. A., \& Jong, S. K. (1995). Menstrual phase-independent retrieval deficit in women with PMS. Biological Psychiatry, 38, 369-377.

Kelsey, J. E., Sanderson, K. L., \& Frye, C. A. (2000). Perforant path stimulation produces seizures, loss of hippocampal neurons, and a deficit in spatial mapping in rats which is reduced by prior MK-80l Behavioural Brain Research, 107, 59-69.

LANDGREN, S. O. (1991). Pregnanolone, a progesterone metabolite, facilitates inhibition of synaptic transmission in the Schaffer collateral pathway of the guinea pig hippocampus in vitro. Epilepsy Research, 10, 156-165.

Majewska, M. D., Harrison, N. L., Schwartz, R. D., Barker, J. L. \& PAUL, S. M. (1986). Steroid hormone metabolites are barbituratelike modulators of the GABA receptor. Science, 232, 1004-1007.

MCAuley, J. W., Reynolds, I. J., KROBOth, F. J., Smith, R. B., \& KroBОтн, P. D. (1995). Orally administered progesterone enhances sensitivity to triazolam in postmenopausal women. Journal of Clinical Psychopharmacology, 15, 3-11.

McCarthy, M. M., Felzenberg, E., Robbins, A., Pfaff, D. W., \& Schwartz-Giblin, S. (1995). Infusions of diazepam and allopregnanolone into the midbrain central gray facilitate open field behavior and sexual receptivity in female rats. Hormones \& Behavior. 29. 279-295.

McCord, D. M., Hamlin, E. D., Pool, G. L., \& Milner. J. S. (1979), Castration, gonadal hormones and sidman avoidance acquisition. Physiology \& Behavior, 22, 601-603.

McCormick, C. M., McNamara, M.. Mukhopadhyay, S.. \& Kelsey, J. E. (1997). Acute corticosterone replacement reinstates performance on spatial and nonspatial memory tasks 3 months after adrenalectomy despite degeneration in the dentate gyrus. Behavioral Neuroscience, $111,518-531$

Miele, J., Rosellini, R. A., \& Svare, B. (1988). Estradiol benzoate can function as an unconditioned stimulus in a conditioned taste aversion paradigm. Hormones \& Behavior, 22, 116-130.

Mora, S., Dussaubat, N., \& Diaz-Veliz, G. (1996). Effects of the estrous cycle and ovarian hormones on behavioral indices of anxiety in female rats. Psychoneuroendocrinologv, 21, 609-620.

O'Connell. A., Earley, B.. \& Leonard, B. E. (1994). Phenylcyclidine prevents spatial navigation and passive avoidance deficits in ibotenate lesioned rats. Neuropharmacology, 33, 1095-1101.

PaCKard, M. G., \& Teather, L. A. (1997). Intra-hippocampal estradiol infusion enhances memory in ovariectomized rats. NeuroReport. 8 , 3009-3013.

Parsons, C., \& Redman, S. (1991). Self-reported cognitive change during pregnancy. Australian Journal of Advanced Nursing, 9, 20-29.

Pellow, S., \& File. S. E. (1986). Anxiolytic and anxiogenic drug effects on exploratory activity in an elevated plus-maze: A novel test of anxiety in the rat. Pharmacology, Biochemistry \& Behavior, 24, 525-529.

PHiLliPS, S. M., \& SherWIN, B. B. (1992a). Effects of estrogen on memory function in surgically menopausal women. Psvchoneuroendocrinology, 17, 485-495.

Phillips, S. M., \& Sherwin, B. B. (1992b). Variations in memory function and sex steroid hormones across the menstrual cycle. Psychoneuroendocrinology, 17, 497-506.

Purdy, R. H., Morrow, A. L., Blinn, J. R., \& Paul, S. M. (1990). Synthesis, metabolism, and pharmacological activity of $3 \alpha$-hydroxy steroids which potentiate GABA-receptor-mediated chloride ion uptake in rat cerebral cortical syntaptoneurosomes. Journal of Medical Chemistry, 33, 1572-1581. 
Rice, M. M., Graves, A. B., McCurry, S. M., \& Larson, E. B. (1997) Estrogen replacement therapy and cognitive function in postmenopausal women without dementia. American Journal of Medicine, 103, 26S-35S

RUPPRECHT, R. (1997). The neuropsychopharmacological potential of neuroactive steroids. Psychiatry Research, 31, 297-314.

SANYAL, M. K. (1978). Secretion of progesterone during gestation in the rat. Journal of Endocrinology, 79, 179-190.

Sharp, K., Brindle, P. M., Brown, M. W., \& Turner, G. M. (1993). Memory loss during pregnancy. British Journal of Obstetrics \& Gynaecology, 100, 209-215.

Sheldrake, P., \& Cormack, M. (1974). Dream recall and the menstrual cycle. Journal of Psychosomatic Research, 5, 347-350.

Sheldrake, P., \& Cormack, M. (1976). Dream recall and the contraceptive pill. Journal of Nervous \& Mental Disease, 163, 59-60.

Silber, M., Almkvist, O., Larsson, B., \& Uvnas-Moberg, K. (1990). Temporary peripartal impairment in memory and attention and its possible relation to oxytocin concentration. Life Sciences, 47, 57-65.

Smith, S. S., Gong, Q. H., Li, X., Moran, M. H., Bitran, D., Hsu, F. C., \& FRYE, C. A. (1998). P withdrawal from $3 \alpha-\mathrm{OH}-5 \alpha$-pregnan20-one using a pseudopregnancy model alters the kinetics of hippocampal GABA-gated current and increases GABA receptor $\alpha 4$ subunit in association with increased anxiety. Journal of Neuroscience, $18,5275-5284$.
Stewart, J., Krebs, W. H., \& Kaczender, E. (1967). State-dependent learning produced with steroids. Nature, 216, 1223-1224.

van Wimersma Greidanus, T. B. (1977). Pregnene-type steroids and impairment of passive avoidance behavior in rats. Hormones \& Behavior, 9, 49-56.

Venault, P., Chapouthier, G., de Carvalho, L. P., Simiand, J., Morre, M., Dodd, R. H., \& Rossier, J. (1986). Benzodiazepine impairs and beta-carboline enhances performance in learning and memory tasks. Nature, 321, 864-866.

Warren, S. G., Humphreys, A. G., Juraska, J. M., \& Greenough, W. T. (1995). LTP varies across the estrous cycle: Enhanced synaptic plasticity in proestrus rats. Brain Research, 703, 26-30.

Wieland, S., Lan, N. C., Mirasedeghi, S., \& Gee, K. W. (1991). Anxiolytic activity of the progesterone metabolite $5 \alpha$-pregnan- $3 \alpha$-ol-20one. Brain Research, 565, 263-268.

WOODFIELD, R. L. (1984). Embedded figures test performance before and after childbirth. British Journal of Psychology, 75, 81-88.

WU, F. S., GibBS, T. T., \& FARB, D. H. (1990). Inverse modulation of $\gamma$ aminobutyric acid and glycine-induced currents by progesterone. Molecular Pharmacology, 37, 597-602.

(Manuscript received July 7, 2000; revision accepted for publication September 11,2000 .) 